Frontispiece: SCOTT ORIOLE 


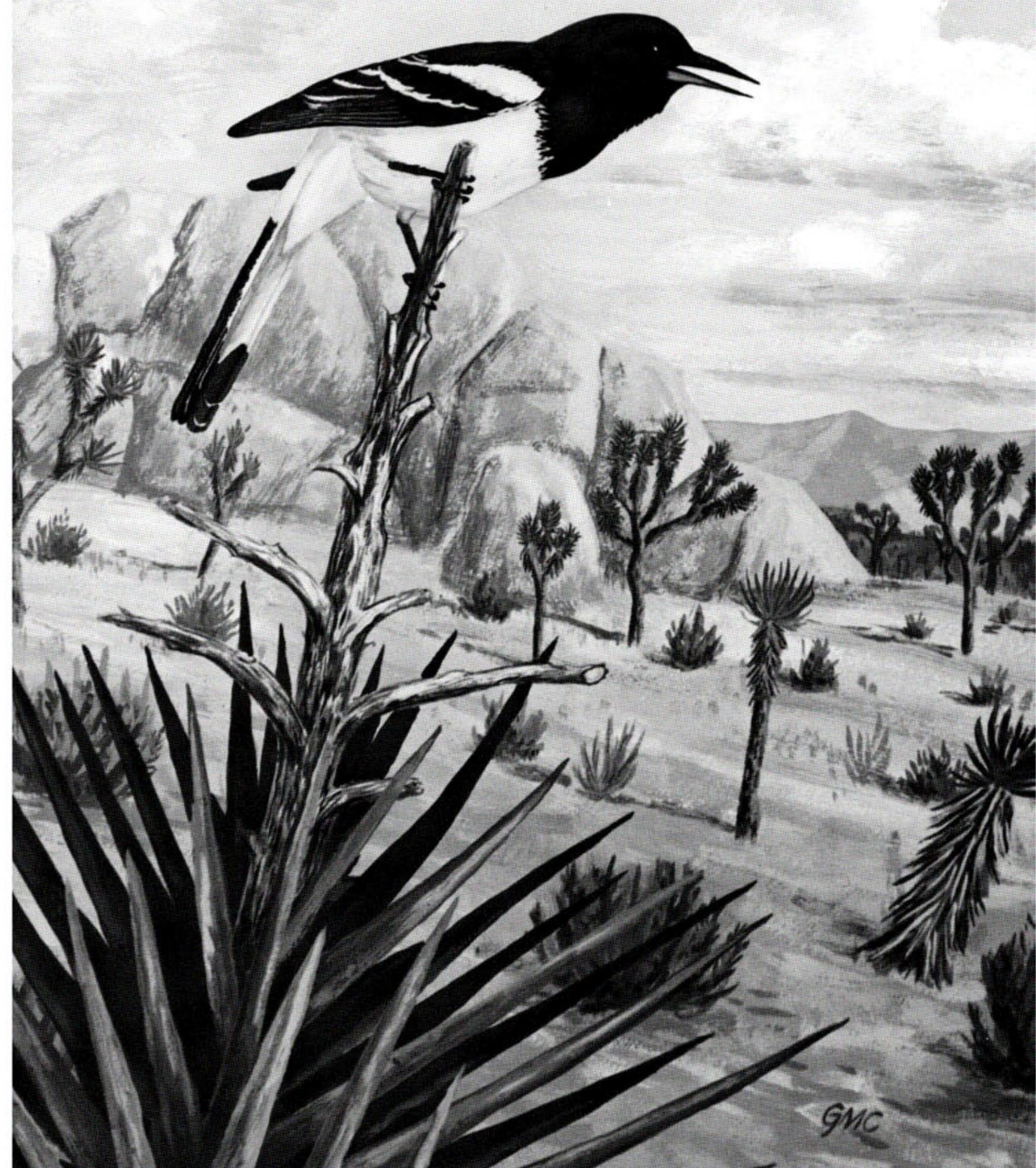




\title{
THE LIVES OF
}

\section{DESERT ANIMALS}

\section{IN JOSHUA TREE}

\section{NATIONAL MONU-}

\section{MENT}

\author{
Alden H. Miller \\ Robert C. Stebbins \\ ILLUSTRATED BY \\ Gene M. Christman
}


UNIVERSITY OF CALIFORNIA PRESS

BERKELEY AND LOS ANGELES, CALIFORNIA

UNIVERSITY OF GALIFORNIA PRESS, LTD.

LONDON, ENGLAND

(C) 1964 BY THE REGENTS OF THE UNIVERSITY OF CALIFORNIA

SECOND PRINTING, 1973

ISBN: $0-520-00866-9$

LIBRARY OF CONGRESS CATALOG CARD NUMBER: 64-18643

DESIGNED BY WILLIAM SNYDER

PRINTED IN THE UNITED STATES OF AMERICA 